\title{
THE STRUCTURE OF THE BLUE RIDGE NEAR HARPER'S FERRY.
}

\author{
BY H. R. GEIGER AND ARTHUR KEITH.
}

(Read before the Society December 31, 1890.)

\section{CONTENTS.}

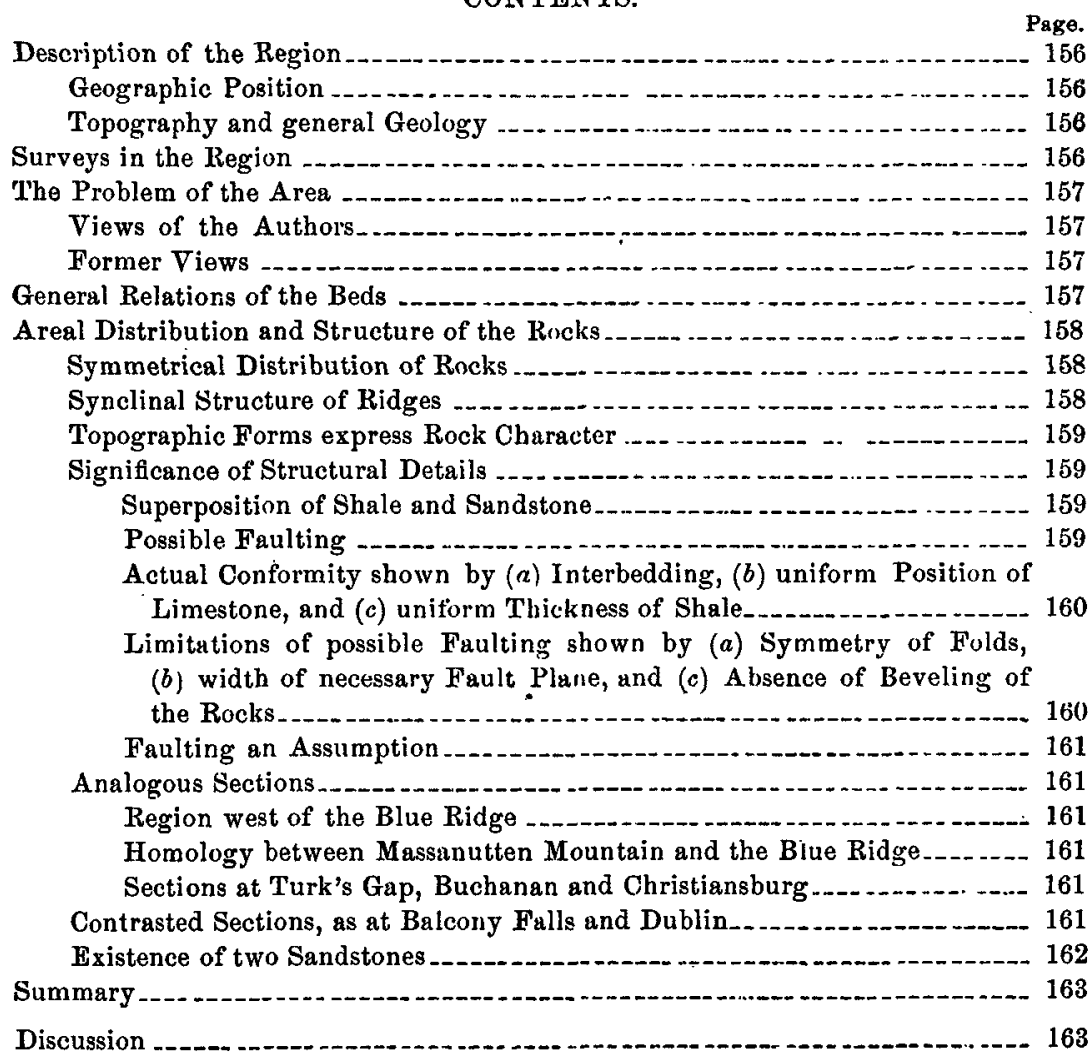




\section{Description of the RegION.}

Geographic Position.-The region discussed in this paper comprises a thousand square miles around Harper's Ferry, about equally divided between Virginia, West Virginia and Maryland.

Topography and general Geology.-The topographic features of the region are, briefly, two mountain lines and three valleys. In order, from west to east, they are Shenandoah valley, Blue ridge, Middletown valley, Catoctin mountain, and Leesburg valley. The position of the ridges is shown on the geologic map by the black areas, the sandstones and the ridges being nearly everywhere coincident.

The last valley is composed of Mesozoic rocks and does not concern the question under discussion; the middle or Middletown valley is composed of schists, injected with granite dikes, and will only be alluded to briefly; the first or Shenandoah valley is occupied by the Potomac and Shenandoah rivers, and is almost entirely floored by the Iower Silurian limestone.

Of the two ridge lines, Catoctin mountain on the east is a single ridge and for the most part formed of sandstone. Over its southern third the summit is made of epidotic schists, and the sandstone retreats to the eastern side. The other mountain line, the Blue ridge, is single more in name than in fact, and usually is a double ridge, with summits of sandstone. This sandstone, like that of Catoctin, leaves the summit to the epidotic schist in its southern part and retreats to the western slope. The main line of what is called Blue ridge in Virginia here laps past the South mountain of Pennsylvania and Maryland. After paralleling each other for twenty miles, each dies away, while the name ("Blue ridge") jumps from one to the other.

West of South mountain and the Blue ridge there is a series of lesser knobs and short ridges in a fairly continuous line. These, like the main ridges, are capped with sandstone. Between the sandstones of the main and lesser ridges and the valley limestones there are calcareous and argillaceous shales. Between the Blue ridge and South mountain there are schists containing eruptive granite, just as in the Middletown valley east of South mountain.

\section{Surveys in the Region.}

The problem of the geologic age of the belt of rocks upon which Harper's Ferry is situated was first approached by the U. S. Geological Survey in 1883. Then the senior author examined the Blue ridge at Balcony falls and in the adjacent country. In subsequent years additional information was gathered at many points by him, and during the last summer by the junior 
author. Other members of the Survey, especially Messrs. McGee and Darton, have at various times made widely separated sections.

\section{The Problem of the Area.}

Views of the Authors.-The general conclusion that the Blue ridge sandstones were not Potsdam, but later, was stated by the senior author and discussed in the Survey, but it was considered only tentative on account of its radical departure from accepted views. The work of the junior author has been to verify and elaborate the stratigraphy deduced by the senior and to prepare the present paper.

Former Views.-The mutual relations of the Shenandoah limestone and the shale and sandstone of the ridges were considered by the Rogers brothers and Lesley, who studied the formations over wide areas, to be limestone on top, shale below that, with sandstone at the bottom. The limestone was considered Cambro-Silurian (Chazy-Calciferous), the shale and sandstone Potsdam. This opinion has been accepted by subsequent geologists and emphasized in various publications. The senior author, however, was unable to verify the accepted ideas and concluded that the series stood in reality sandstone on top, shale below that, with limestone at the bottom. To these rocks the present discussion is limited.

\section{General Relations of the Bens.}

On a general view of the formations in question, it is obvious that the Shenandoah limestone dips eastward under the shale and sandstone of the ridges. This is in the great majority of cases true and is commented on by W. B. Rogers in various parts of his reports. To explain it, earlier geologists have been obliged to consider the series overturned, an actual easterly dip thus representing a theoretical westerly dip. In some sections across a single sequence of the formations this could not be gainsaid, but a repetition of the beds brings out their actual relations and they are obviously not overturned, but normal.

The limestone of the Shenandoah valley forms a wide series of open and closed folds, disappearing under the mountain with easterly dips. The mountain sandstone and shale form synclines throughout, with the single exception of Catoctin mountain, where the syncline is in places bisected by a fault. These synclinal axes are prolonged from the mountain ends into synclines of the Shenandoah limestone and the parallel bands of rock swing around the mountain ends.

On structural evidence, therefore, the sandstone is higher than the lime. stone. To prove anything else requires the evidence of fossils, but none 
have been found outside of the Shenandoah limestone. To this datum, then, we must refer the sandstone and shale by structural relations alone.

To determine the exact structural relations, the areas of the formations have been carefully worked out and large numbers of observations have been made as to the attitude of the beds.

\section{Areal Distribution and Structure of the Rocks.}

Symmetrical Distribution of Rocks.-The accompanying map (plate 4) shows the distribution of the rock-masses in practically all the detail of nature. Inspection of the areas of distribution, especially in the northern part, discloses a symmetry among them; belts of one rock encircle others. The symmetry indicates a definite relation between the beds involved, and its precise nature is brought out by the accompanying sections. The sections (plate 5) are at intervals of one to six miles, as shown on the map by broken lines, and are so placed as to bring out all material changes of structure.

Synclinal Strueture of Ridges.-At a glance it is apparent that the synclinal type prevails in the mountains. There are some sections of close folds that are not in themselves decisive of structure, but a few miles away, along the same outcropping line, all doubts vanish and the structure is simple. This is notably the case at the Harper's Ferry gaps in the Blue ridge and South mountain.

The clean-cut Potomac section is so folded and complex as to be open to discussion at least. But in three miles either northward or southward along the Blue ridge, indecision is replaced by certainty when the tangle of the gap section is transformed to open normal folds. Southward the folds continue open throughout; northward they open and close alternately.

South mountain presents the same synclinal features. Northward from the Potomac, erosion cuts three times through the sandstone belt into the underlying slates. Eight miles southward from the Potomac, the closed syncline of the river section is cut through by erosion. South of this gap a patch of the sandstone is left in Short hill before the axis finally pitches upward and South mountain disappears.

On Catoctin mountain the synclinal sandstone is entirely cut through by the Potomac, leaving the underlying slates along the surface. Both northward and southward from the river the structure is the same. The synclinal axis pitches down until in three miles its eastern half is cut off by the post-Newark fault. Some distance north, in Maryland, Catoctin and South mountains nearly if not quite unite.

The lesser sandstone knobs before mentioned are mere remnants in a general synclinal axis. Some parts of the axis are flat, some are closely folded. In many cases no ledges occur to furnish dip observations, but the sand- 


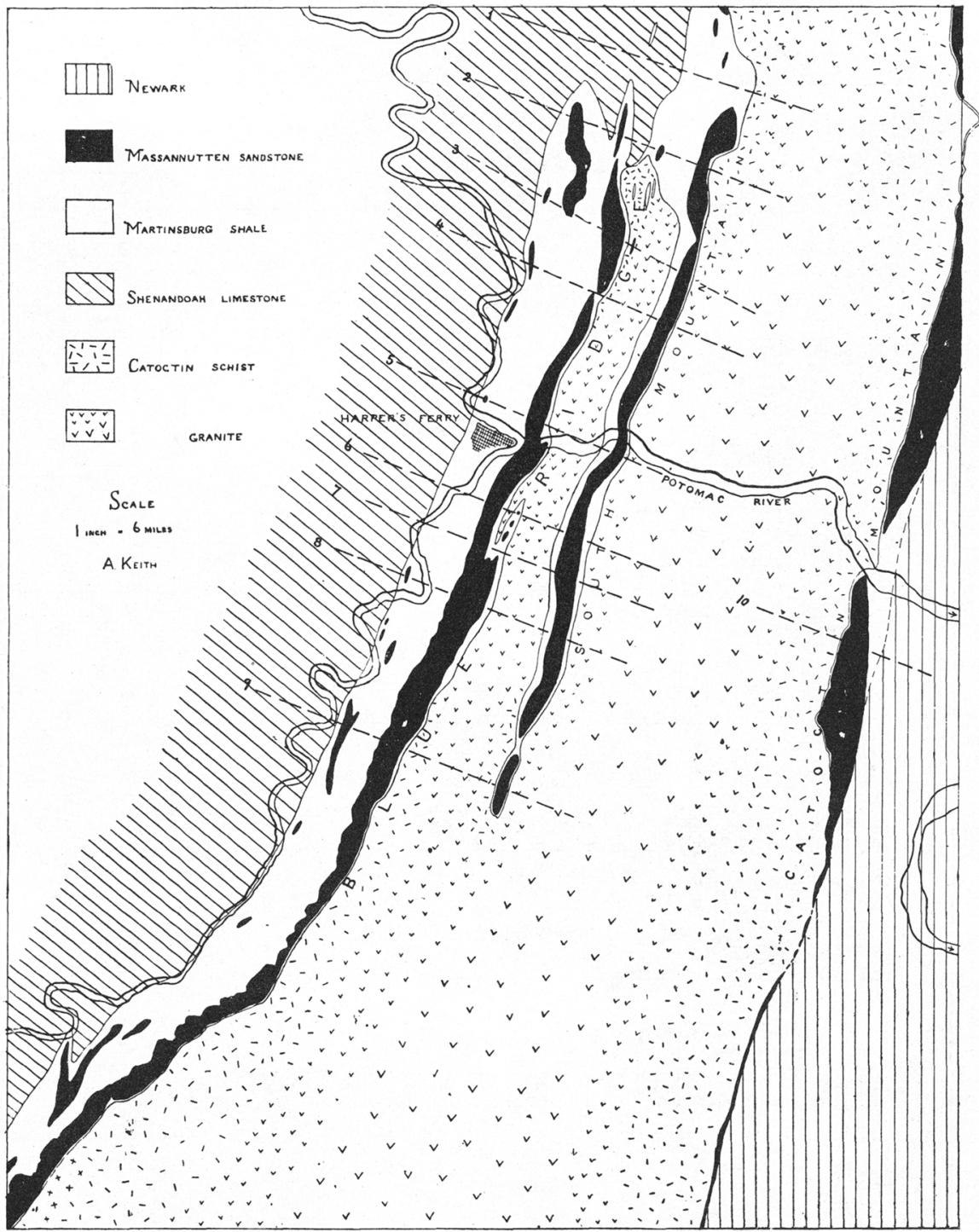

GEOLOGIC MAP OF HARPER'S FERRY REGION. 
Downloaded from gsabulletin.gsapubs.org on August 3, 2015

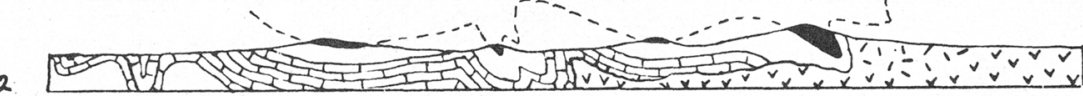

3

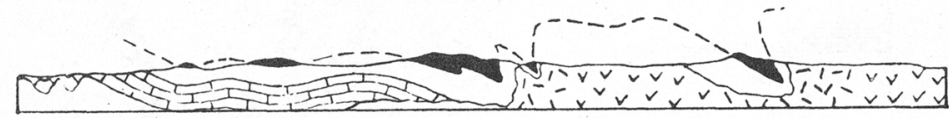

4
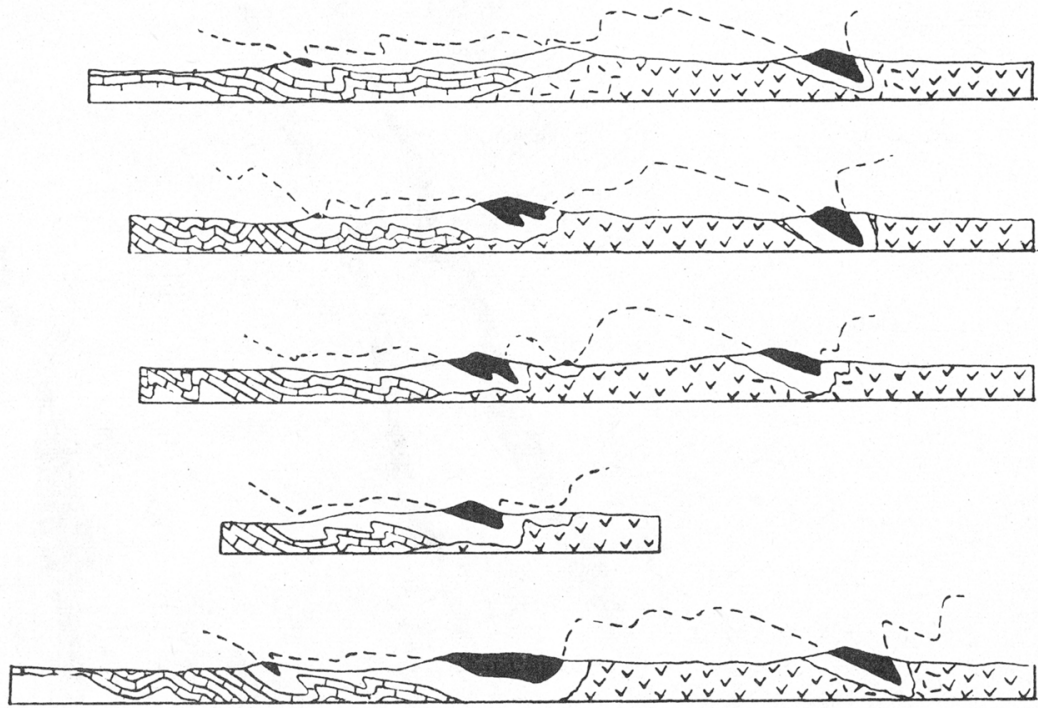

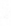

9
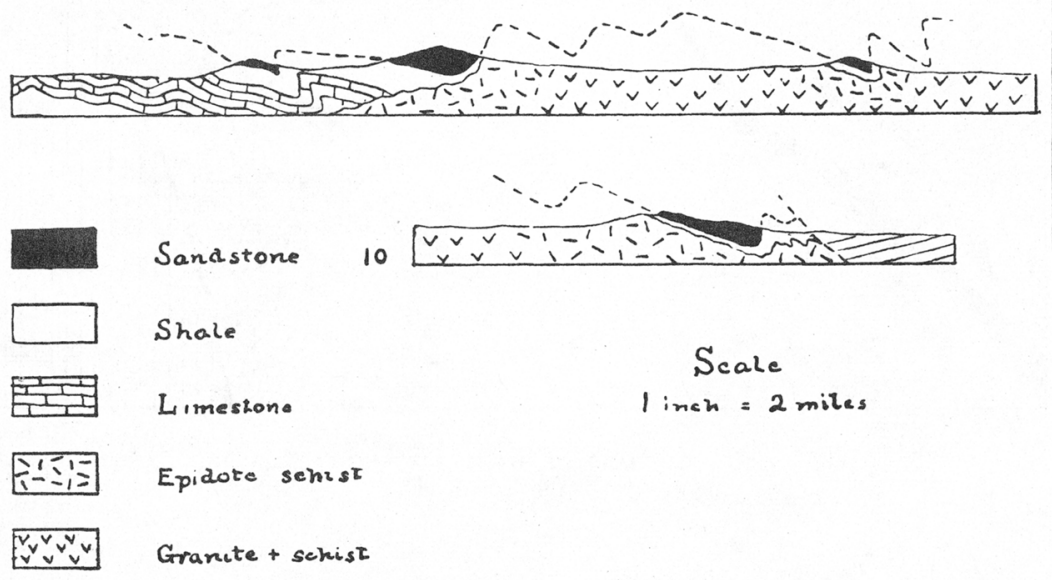

Shale

Limestone

Seale

1 inch $=2$ miles

Epidote sehrst

Grancte + schist 
stones are caps of hilltops surrounded by slopes of shale, so that they can be nothing but synclines in structure.

Topographic Forms express Rock Character.-The difference in continuity between the portions of the major and the minor ridges is the expression of a difference in texture of the retaining sandstones. The continuous lines are made by a white and gray sandstone, often a silicious conglomerate, which is of great durability; the interrupted lines are formed by a fine white sandstone, which is less silicious and consequently more subject to erosion. The effect of this textural difference on the topography is exaggerated by external relations in most places. Adjacent to the fine sandstone is the easily eroded limestone. Over this the Shenandoah river plays so that this sandstone is readily within reach of erosion. The heavy sandstone, on the other hand, is usually flanked by an area of epidotic schist, which is exceedingly hard and tough, and is also defended on the other side by the lesser sandstones. The subordinate position thus maintained by the outer sandstone has led geologists to ignore its importance; but the value of careful mapping of both types can hardly be overestimated. Each occurrence multiplies the chance for observing the structural relations in a given area and hence strengthens the conclusions based on structure.

The distinct difference between the types would indeed suggest a difference in age, and Rogers has represented them as different. But this distinction of type, like most others, is accompanied by an intermediate gradation, and one sandstone visibly changes to the other in one continuous line. This is the case at the northern end of the Blue ridge proper, and is made manifest at a distance by the gradual tapering of the ridge.

Significance of Structural Details: Superposition of Shale and Sandstone.The sections shown in plate 5 are constructed from observed dips. From these sections it is plain that the shale-sandstone series rests on the limestone, apparently deposited there as sediment. If deposition gave them their present position, $i$. e., if the present sequence is original, they are unquestionably Silurian. Can they by any process have attained that position so as to simulate deposition? If so, what are the attendant features elsewhere, and are they present here?

Possible Faulting.-There is one structure able to produce similar effects, i. e., faulting succeeded by later folding. In this case the plane of overthrust would afterward be folded with the adjacent beds. Such a structure has been discussed by Mr. Hayes at this meeting of the Society.* It is decidedly an exceptional structure and as such requires the best of proof, either fossils or unconformity of rock-masses. Fossils of early forms in the overlying beds contrasted with late forms in the underlying beds are of course, as $\mathrm{Mr}$. Hayes states, final proof. Without fossils, visible unconformities of texture 
and dip in adjacent beds and wide differences in adjacent sections are equally good proof. Both have been described by Mr. Hayes, and both have been observed by the junior author.

What is the case here? Fossils occur in the Shenandoah limestones showing their equivalence to the Chazy-Calciferous of New York. Outside of the limestone none have been found; therefore we must look for unconformity to prove that appearances are not true, and we must find it between the limestone, the datum formation, and the sandstone, which is the top of the section.

Actual Conformity.-Of unconformity, however, in that place there is not the least suggestion. Between the shale and the granite-schist series east of the Blue ridge there is unconformity of the ordinary type of deposition, but that does not affect the question. (a) In individual sections the limestone is interbedded with shale, the sandstone with the shale and the shale with the sandstone. (b) It is, moreover, the same horizon of the limestone in contact with the shale. Most strata of the limestone, it is true, cannot be positively identified, but a thin bed of white marble and slate can be, and that occurs repeatedly only 400 feet below the shale. (c) The general section is a unit from one end of the region to the other; limestone, 500-600 feet of shale, sandstone. Fifteen different sandstone areas next the limestone along thirtyfive miles give the same sequence. This thickness of shale is small, but it is very uniform, and by its very smallness makes the uniformity more certain, because it is more accurately measured and would be more easily removed by a fault.

Limitations of possible Faulting.-The possibility of a fault is practically removed, even where there is only a single sequence of limestone and shale. (a) Where, as in the sections shown in plate 5, there are four or five repetitions in a direct cross-section of as many miles, the case is so extreme that the hypothesis of a fault is entirely excluded. In order to have existed without impairing the symmetry of the folds the fault must have followed the course of the shale bed 500 feet thick. (b) The present width of this possible fault plane would be three and a half miles at the end of the Blue ridge, with the corrugated surface of the shale bed. Its actual width, measured along the shale bed, would be five miles. This is entirely within the reach of the great overthrust faults known in the Appalachians, so far as mere distance of thrust is concerned, but the character of thrust is entirely different. (c) Various broad thrust planes in Tennessee studied by Hayes and the junior author show a marked unconformity in stratigraphy along the line of break. 'While the difference of dip rarely is much, the rocks of the down-thrust lie along the bevelled edges of the up-thrust and vice versa. Sometimes one, sometimes the other is bevelled, but the over and under series bear no relation to one another. Here the case is quite different. Instead 
of unconformity and bevelled edges there is perfect correspondence on either side of the supposed fault, not in a single section only, but in all adjacent to the limestone, both along and across the folds. A great fault can with difficulty be imagined that would trim the bed so neatly; certainly none has been observed.

Faulting an Assumption.-With all structural and stratigraphical facts the reverse of those connected with faults, and with the lack of fossils to demonstrate a fault, it is clear assumption to say that there is one. There is nothing to indicate a fault; therefore we are obliged to return to the view that the beds were sedimentary deposits in their present relations-limestone under the shale and sandstone.

Analogous Sections.-Region west of the Blue Ridge.-This view is the first and natural one, and is supported by the existence toward the west of a similar series in a similar attitude-i. e., the Shenandoah limestone, the Martinsburg shale (equivalent to the Hudson river), and the Massanutten sandstone (equivalent to the Medina). Comparison of these sections makes the Blue ridge shale Hudson River and the sandstone Massanutten or Medina.* It is through a precisely similar comparison that. these sandstones were called Potsdam, and the lithological correlation is in one case as strong as in the other.

Homology between Massanutten Mountain and the Blue Ridge.-Additional sections of the Blue ridge to support our view are readily found in other places. Rogers frequently states that the sandstones of the Blue ridge appear to be above the limestone. The same general relation holds all along the Massanutten mountain and adjacent points in the Blue ridge. The structure is an anticlinal valley of Shenandoah limestone between two synclinal ridges. The Massanutten synclinal is accepted Silurian ; from its structure the Blue ridge is the same, and no fossils have proved the opposite.

Sections at Turk's Gap, Buchanan and Christiansburg.- Twenty-five miles southwestward, at Turk's gap, two flat synclines of sandstone nearly cover the Blue ridge. Sixty miles southwestward, at Buchanan, the Massanutten section is duplicated-an anticlinal of limestone between a Silurian sandstone syncline and the eastward-dipping Blue ridge sandstone. Forty miles farther southwestward, near Christiansburg, the Blue ridge sandstone rests on shale and that in turn on the Shenandoah limestone, the whole series dipping southeastward 10 degrees. These are instances taken from numerous occurrences, and their use here is merely to corroborate. None the less, these facts, both in nature and closeness of correlation, are of the same grade as those cited by Rogers to support his view.

Contrasted Sections, as at Balcony Falls and Dublin.-It will seem strange to most geologists that Rogers and others dealing with the question should

* The names "Massanutten," "Martinsburg," and "Shenandoah" are derived from Massanutten mountain, Martinuburg, and Shenandoah river, all in West Virxinia. The mountain, town and river are charac terized respectively by the sandstone, shale, and limestone. 
have embraced a view so at variance with these facts. It is due to them to say that not all the facts are against them. In various portions of the Blue ridge there are sandstones dipping northwestward or toward the valley limestone, and the facts are susceptible of the interpretation that the sandstones are beneath the limestone. The section at Balcony Falls appears to show an underlying sandstone. One unequivocal case of underlying sandstone has been found by Darton five miles east of Dublin, where a visible anticline of sandstone lies under an extensive arch of valley linestone. Without doubt other cases will be demonstrated by closer study, and doubtful cases are already known.

Existence of two Sandstones. - It seems from the foregoing facts that there are two sandstones, one above and one below the valley limestone. There is nothing unusual about such an arrangement; among the fossiliferous series it is very common. Three or four times in the vertical column the same lithologic character recurs; but this simply indicates a renewal of similar conditions of sedimentation and has no bearing on age. There is no reason to suppose that these conditions did not exist before the limestone was deposited. Among the fossiliferous rocks the fossils enforce a discrimination of the sandstones; in the Blue ridge they do not. In their absence nothing but structural evidence can discriminate, and that, in the case of Rogers at least, was forbidden hy the amount of ground to be covered. The mistake was made of correlating distinct and distant sections with insufficient connection by areas. It was, apparently, enough that they contained a group of rocks similar in texture and lay in the same topographic belt. In other words, instead of structure, lithology was made the basis of correlation, in spite of its unreliability in adjacent areas.

Certain cross-sections were taken as typical, and from them a stratigraphy was deduced. Into this mold the other observations were poured with the inevitable result that some of them, to put it mildly, lost their original character. Rogers' published sections of the Blue ridge at Harper's Ferry and Ashby's gap are distinctly wrong. In the former the limestone does not dip northwestwgrd and the shale under it, as represented: nor does any sandstone bed reach water level until the main ridge is reached; nor is the sandstone-shale series a simple monoclinal sequence, but a highly contorted synclinal depression. His section a little south of Harper's Ferry gives the open syncline of Blue ridge as it is, but adds thereto a series of vertical sandstones that have no existence whatever. In his section at Ashby's gap, at the southwestern corner of the region under discussion, a synclinal ridge-cap is turned into a monoclinal bed; the low southeastward dips on the main ridge are shown, but the equally plain northwestward dips are not.

Rogers' sections show that he appreciated the want of harmony of his different observations and the difficulty of reconciling them. In view of the ob- 
stacles to unity that he found, it would be extremely hazardous in us to state that all the Blue ridge sandstones are upper Silurian. It is perfectly reasonable that Cambrian sandstones exist in this topographic line. They exist in Tennessee of various types, and with equal certainty Silurian sandstones are almost side by side with them. In Tennessee they have been confounded; why not in Virginia? To establish their existence here, no single section, much less a single sequence of the beds, will suffice. Nothing in Appalachian geology is less certain than a single sequence. A profound fault may cut it without a trace ; the beds may be turned upside down ; an interval of erosion or of non-deposition may intervene and no record be left. Each of these is of frequent occurrence, and each may produce the same section. In detailed work along the outcrop lies the only structural proof.

In this region above most others nature has concentrated the means of proof, and by frequently repeating the phenomena has clarified and emphasized them. The responsibility thrown on a single section has been diminished until error is practically eliminated.

\section{Summary.}

To sum up, there is no à priori reason to call these sandstones either Potsdam or Silurian.

The series lies in synclines above the Shenandoah limestone.

The beds grade from one to another and are conformable by dip.

The series is the same along the strike throughout the area. Apparently this is their original position as sediment, and they are Silurian. If this position was acquired after deposition, it could only be by means of a remarkable fault with none of a fault's characters and nothing to suggest its existence.

In Tennessee there are both Cambrian and Silurian sandstones in proximity. In Virginia the facts are discordant in different areas and probably there are two sandstone horizons.

Here the net of facts is close and all point to one conclusion : our contention simply is-here there are upper Silurian saudstones.

Washington, D. C., December 28, 1890.

\section{DISCUSSION.}

Mr. C. D. W ALcort : In the Adirondack region of north western New York the Potsdam sandstone rests on pre-Cambrian rocks and is succeeded by the Calciferous, Trenton and Hudson strata. On the southwest the Trenton limestone is in contact, by overlap, with the pre-Cambrian rocks, not having been removed by erosion; and above it we find to the westward the Lorraine 


\section{GEIGER AND KEITH-STRUCTURE OF THE BLUE RIDGE.}

shales and Oswego and Medina sandstones. Along the western side of the Green mountains and southward through New York and New Jersey we have Cambrian sandstone and Lower Silurian limestone and shale in successive order, while in the Blue ridge section, described by Messrs. Geiger and Keith, the succession is, limestone, shale, sandstone, as in the Silurian section of New York just mentioned. In the latter case erosion has evidently not cut through the Silurian limestone to the Cambrian; and the section is that of an overlapping deposit upon a sloping pre-Paleozoic shore-line, similar to that about the Adirondack region. From these facts I think it probable that the interpretation of Messrs. Geiger and Keith is the correct one.

Professor C. H. Hгтснсоск: If the authors allow that the reference of the quartzites next the crystallines to the middle Silurian applies only to the region of Harper's Ferry, they may be correct. I understood them, however, to claim the reference of the whole of W. B. Rogers' number 1 to this horizon, insisting that no reliance should be placed upon the sections at Balcony Falls and near Christianshurg, where the sandstones or quartzites underlie the lower Silurian limestones. I am familiar with this part of the great valley of Virginia, and should interpret the structure as Rogers and Campbell have done, both by reason of the stratigraphy, and because fragments of the crystalline rocks further east are constituents of the basal conglomerates, which in their turn underlie the limestones. The presence of fragments of the older rocks in the derived sediments affords a better criterion for the determination of the succession of the terranes on the western flank of the Blue ridge than their dips. One can explain the presence of eastern dips by inversions or faults if necessary, but cannot understand how a composite sedi. ment can be older than its constituent rounded pebbles. Thirty years since our best geologists overlooked this obvious principle in explaining the structure of these same rocks in western New England and referred the quartzites to the Medina; to-day there is not a single geologist familiar with the ground who would accept the early views of Logan, Hall and Dana in reference to this point. Hence these Harper's Ferry outcrops must represent only local dispositions.

Major JED HoTCHKIss: Can the authors of the communication inform us concerning the age and relations of the limestones frequently found east of the Blue ridge?

Mr. KeITh : Limestones sometimes occur as small lenses in slate over the Archean area east of the Silurian limestones of the Shenandoah valley. In one case (near Sharpsburg) the Silurian limestones rest on shales which may be Cambrian. 


\title{
Geological Society of America Bulletin
}

\section{The Structure of the Blue Ridge Near Harper's Ferry}

\author{
H. R. GEIGER and ARTHUR KEITH
}

Geological Society of America Bulletin 1891;2, no. 1;155-164 doi: 10.1130/GSAB-2-155

Email alerting services

Subscribe

Permission request click

www.gsapubs.org/cgi/alerts to receive free e-mail alerts when new articles cite this article

click

www.gsapubs.org/subscriptions / to subscribe to Geological Society of America Bulletin

click

http://www.geosociety.org/pubs/ copyrt.htm\#gsa to contact GSA

(C) 1891 Geological Society of America

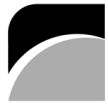

THE GEOLOGICAL SOCIETY 
Copyright not claimed on content prepared wholly by U.S. government employees within scope of their employment. Individual scientists are hereby granted permission, without fees or further requests to GSA, to use a single figure, a single table, and/or a brief paragraph of text in subsequent works and to make unlimited copies of items in GSA's journals for noncommercial use in classrooms to further education and science. This file may not be posted to any Web site, but authors may post the abstracts only of their articles on their own or their organization's Web site providing the posting includes a reference to the article's full citation. GSA provides this and other forums for the presentation of diverse opinions and positions by scientists worldwide, regardless of their race, citizenship, gender, religion, or political viewpoint. Opinions presented in this publication do not reflect official positions of the Society.

\section{Notes}

(C) 1891 Geological Society of America 